\title{
Role of somatic cells on dairy processes and products: a review
}

\author{
N. Li • R. Richoux • M. Boutinaud • P. Martin • \\ V. Gagnaire
}

Received: 3 April 2014 /Revised: 28 May 2014 /Accepted: 16 June 2014 /

Published online: 17 July 2014

(C) The Authors 2014. This article is published with open access at Springerlink.com

\begin{abstract}
Somatic cells are an important component naturally present in milk, and somatic cell count is used as an indicator of udder health and milk quality. The role of somatic cells in dairy processes and products is ill-defined in most studies because the role of these cells combines also the concomitance of physicochemical modifications of milk, bacterial count, and the udder inflammation in the presence of high somatic cell count. The aim of this review is to focus on the role of somatic cells themselves and of endogenous enzymes from somatic cells in milk, in dairy transformation processes, and in characteristics of final products overcoming biases due to other factors. The immune function of somatic cells in the udder defense and their protective role in milk will be primarily considered. Different characteristics of milk induced by various somatic cell counts, types, and their endogenous enzymes influencing directly the technological
\end{abstract}

N. Li • V. Gagnaire

INRA, UMR 1253, Science et Technologie du Lait et de l'Euf, 65 rue de Saint Brieuc, F-35042 Rennes, France

N. Li • V. Gagnaire $(\bowtie)$

Agrocampus Ouest, UMR 1253, Science et Technologie du Lait et de l'Euf, 65 rue de Saint Brieuc, 35042 Rennes, France

e-mail: valerie.gagnaire@rennes.inra.fr

N. $\mathrm{Li} \cdot \mathrm{R}$. Richoux

Actalia, BP 50915, 35009 Rennes, Cedex, France

M. Boutinaud

INRA, UMR 1348, Physiologie, Environnement et Génétique pour l'Animal et les Systèmes d'Élevage, 35590 Saint Gilles, France

M. Boutinaud

Agrocampus Ouest, UMR 1348, Physiologie, Environnement et Génétique pour l'Animal et les Systèmes d'Élevage, 35590 Saint Gilles, France

P. Martin

INRA, UMR 1313, Génétique Animale et Biologie Intégrative, 78350 Jouy-en-Josas, France

P. Martin

AgroParisTech, UMR 1313, Génétique Animale et Biologie Intégrative, 78350 Jouy-en-Josas, France 
properties of milk and the final quality of dairy products will be discussed as well. By comparing methods used in other studies and eliminating biases due to other factors not considered in these studies, a new approach has been suggested to evaluate the effective role of somatic cells on dairy processes and products. In addition, this new approach allows the characterization of somatic cells and their endogenous enzymes and, in future research, will allow the clarification of mechanisms involved in the release of these components from somatic cells during dairy processes, particularly in cheese technologies.

Keywords Milk $\cdot$ Somatic cells $\cdot$ Enzymes $\cdot$ Cathepsin D $\cdot$ Cheese

\section{Introduction}

Milk is known to be a high-value nutritional biological fluid composed of water, proteins, fat, sugars, minerals, etc. Other important components existing naturally in raw milk are somatic cells (SCs), and the predominant cell type, besides shed epithelial cells, in most species is leucocytes, including macrophages, polymorphonuclear neutrophils cells (PMNs), and lymphocytes (Boutinaud and Jammes 2002).

The amount of SCs, usually called somatic cell count (SCC), in milk is used as an important indicator of udder health since SCs are involved in protecting the mammary gland from infection as part of the innate immune system. SCC in milk is influenced by many factors, such as animal species, milk production level, lactation stage, and also the individual and environmental factors as well as management practices (Rupp et al. 2000). Though SCC is subjected to variation, it is still used as an indicator of milk quality in several species, especially in ruminant and human (Hunt et al. 2013; Sharma et al. 2011). Taking cow milk as an example, when SCC $>2 \times 10^{5}$ cells. $\mathrm{mL}^{-1}$, the udder is considered to be infected, and when SCC $>4 \times 10^{5}$ cells. $\mathrm{mL}^{-1}$, the milk is deemed unfit for human consumption in the European Union (EU). The legal SCC threshold for milk acceptance in dairy industries varies in different countries, e.g., the values for bovine milk in Germany, Canada, and the USA are $1 \times 10^{5}, 5 \times 10^{5}$, and $7.5 \times 10^{5}$ cells. $\mathrm{mL}^{-1}$, respectively (Olechnowicz and Jaskowski 2012; Schwarz et al. 2011). For caprine and ovine milk, the cutoff value is $1 \times 10^{6}$ in the USA but is not yet defined in the EU (Council Directive 92/46/EEC 1992).

Whether SC is "a friend or a foe" in the dairy field remains a question (Souza et al. 2012). Generally, SCs until now have been considered as negative. High SCC is associated with udder inflammation, which leads to bacteriological problems in milk, an alteration of milk composition, and finally, the major modifications of dairy product characteristics compared to the normal values (Le Maréchal et al. 2011; LindmarkMansson et al. 2006; Raynal-Ljutovac et al. 2007; Sharma et al. 2011). However, besides their immune function in the udder and protective functions in milk, SCs have recently been shown to influence, in a positive way, the composition and technological properties of dairy products, thus participating in the final quality of dairy products through their endogenous enzymes (Sanchez-Macias et al. 2013; Souza et al. 2012).

The role of SCs is generally assessed as a global effect, although the influence of the other factors has not been considered separately, and then, includes intrinsic characteristics of milk modified by the inflammation of the mammary gland, consequences on 
milk biosynthesis and secretion, and bacterial count (Albenzio et al. 2004; O'Farrell et al. 2002; Raynal-Ljutovac et al. 2007). Few research studies until now have given a clear view of the role of SCs without the combination of the other causative factors. This review focuses on the state of our knowledge of SCs in the dairy field and on their effective role in dairy processes and products.

\section{Somatic cells and udder defense mechanism}

\subsection{The immune function of somatic cells in the udder}

SCs are known to be one of the major defense components of the mammary gland against disease or intramammary infections (Paape et al. 1979, 2002; Sharma et al. 2011). The four main cell types composing SC, namely, macrophages, PMNs, lymphocytes, and epithelial cells, are briefly presented in Table 1.

Macrophages are generally the predominant cell type in healthy cow milk. They can fight against bacterial invasion quickly by engulfing action. In the case of infection, macrophages release chemical messengers or chemoattractants that are detected by PMNs and direct PMNs in turn towards the infection site. Both macrophages and PMNs can ingest microbial cells by phagocytosis and have an essential role in the innate immune system. Moreover, macrophages participate in the specific immunity as do lymphocytes (Burvenich et al. 2003).

PMNs can be recruited and increase milk SCC when the infection continues. They can be present to a large extent in mastitic milk, even up to $92 \%$ in bovine milk (Paape et al. 1979). When PMNs arrive at the site of infection, they phagocyte microorganisms and kill them by using a combination of oxidative and non-oxidative mechanisms (Pham 2006).

Lymphocytes have a determinant role in the specific immune system. They are the only cells able to recognize the antigens through specific membrane receptors for invading pathogens (Sordillo et al. 1997).

Table 1 Characteristics and composition of somatic cells in healthy milk of different species

\begin{tabular}{|c|c|c|c|c|c|}
\hline & Macrophages & PMNs & Lymphocytes & Epithelial cells & References \\
\hline $\begin{array}{l}\text { Image of bovine } \\
\text { somatic cells stained } \\
\text { by methylene blue }\end{array}$ & & & & & ISO 13366-1/IDF148-1 \\
\hline $\begin{array}{l}\text { Morphological } \\
\text { characteristics }\end{array}$ & - Big nucleus & - Plurilobery nucleus & - Dense and round nucleus & - Round nucleus & ISO $13366-1 / 1 \mathrm{DF} 148-1$ \\
\hline Biological functions & $\begin{array}{l}\text { - Phagocytosis } \\
\text { - Intracellular killing of } \\
\text { bacteria } \\
\text { - Presentation antigen } \\
\text { - Secretion of } \\
\text { chemoattractants }\end{array}$ & $\begin{array}{l}\text { - Phagocytosis } \\
\text { - Intracellular killing of } \\
\text { bacteria } \\
\text { - Secretion of antibacterial } \\
\text { factors } \\
\text { - Detection of } \\
\text { chemoattractants }\end{array}$ & $\begin{array}{l}\text { - Specific immune system } \\
\text { - Production of immune } \\
\text { regulatory cytokines } \\
\text { - Lysis of altered or } \\
\text { damaged host cells }\end{array}$ & $\begin{array}{l}\text { - Secretion of } \\
\text { chemoattractants }\end{array}$ & $\begin{array}{l}\text { Burvenich et al. 2003; Lee et al. } \\
\text { 1980; Paape et al. 1979; Paape et } \\
\text { al. 2002; Paape et al. 2003; } \\
\text { Sordillo et al. 1997; Sordillo and } \\
\text { Streicher } 2002\end{array}$ \\
\hline \multicolumn{6}{|c|}{ Percentage of each cell type in milk of different species } \\
\hline \multirow[t]{5}{*}{ Bovine } & $35-79^{\mathrm{a}}$ & $3-26$ & $16-28$ & $2-15$ & ISO13366-1/IDF148-1 \\
\hline & 26 & 16 & 23 & $36^{\mathrm{a}}$ & Benic et al. 2012 \\
\hline & 40 & 10 & $50^{\mathrm{a}}$ & - & Rivas et al. 2006 \\
\hline & $60^{\mathrm{a}}$ & 12 & 28 & - & Marino et al. 2005 \\
\hline & 13 & 28 & 29 & $45^{\mathrm{a}}$ & Leitner et al. 2000b \\
\hline \multirow[t]{2}{*}{ Sheep } & $46-84^{a}$ & $2-28$ & $11-20$ & $1-2$ & Gonzalez-Rodriguez et al. 1995 \\
\hline & $57^{\mathrm{a}}$ & 31 & 8 & 2 & Morgante et al. 1996 \\
\hline \multirow[t]{2}{*}{ Goat } & $15-41$ & $45-74^{\mathrm{a}}$ & $9-20$ & 6 & Dulin et al. 1983 \\
\hline & 11 & 79 & 10 & - & Boulaaba et al. 2011 \\
\hline
\end{tabular}


Mammary epithelial cells are the cells that produce milk. They are shed from the mammary epithelium during lactation (Boutinaud and Jammes 2002). Prior to 1980, they were confused with macrophages because of their similar morphological traits and finally discovered in milk by electron microscopy (Lee et al. 1980). The epithelial cells are the first defense line of the mammary glands, and they may participate in the immunity of neonates in different species (Boutinaud and Jammes 2002). This type of cell is often detected below $15 \%$ (Table 1) as also confirmed in other studies (Ben Chedly et al. 2011; Boutinaud et al. 2008; Rankl 2004). The mammary epithelial feature of these cells has been further determined in cows and goats using transcriptomic and proteomic analyses, demonstrating that their content in mRNA and proteins, such as cytokeratin and enzymes involved in milk synthesis, is specific to mammary epithelial cells (Ben Chedly et al. 2011; Boutinaud et al. 2008; Janjanam et al. 2013).

\subsection{The protective function of somatic cells in milk}

Besides the immune defense role in the udder, SCs can continue their protective function in milk. Additionally, some components identified as being from SCs are present in milk and also help to enhance the host defense. For example, PMNs have bactericidal and respiratory burst activities and they can eliminate the invading bacteria by releasing reactive oxygen species (ROS) and granular enzymes (Paape et al. 2002). Some antibacterial proteins identified in bovine milk also arise from SC such as macrophage scavenger receptor types I and II, PMN peptidoglycan recognition protein and lymphocyte cytosolic protein 1 and cathelicidins. They can continue to exert their protective properties when they are in skim milk, whey, or milk fat globule membranes (Hettinga et al. 2011; Smolenski et al. 2006). Recently, information was obtained on the protein changes of the bovine and goat innate immune system following exposure to lipopolysaccharide (LPS) from the cell walls of gram-negative Escherichia coli, leading to an increase in SCC without having the contribution of bacteria themselves (Hinz et al. 2012; Olumee-Shabon et al. 2013). In both ruminant species, an increase in the antimicrobial proteins was observed and more precisely of cathelicidins, which are involved in the degranulation of PMNs. In caprine milk, acute-phase proteins, haptoglobin, and serum amyloid A were shown in milk collected after $18 \mathrm{~h}$ after infusion with LPS.

The enzymes initially from SCs can be released or secreted in milk and are therefore considered as endogenous SC enzymes and play an important protective role in milk. The role of the lysozyme, one SC endogenous enzyme, is well known for the ability to destroy bacteria (Paape et al. 2003). Some proteinases from PMNs, such as cathepsin $\mathrm{G}$, elastase, and proteinase 3 , have antimicrobial activities during phagocytosis of invading microorganisms. They could also contribute, after release, to the extracellular killing of microorganisms by cleaving their bacterial virulence factors as shown in mice (Pham 2006). Catalase, an endogenous enzyme from PMNs, is one of the main antioxidant enzymes in milk and is suspected of being responsible for changed redox potential of milk that limited the survival capability of microorganisms (Hamed et al. 2008).

Even if the release mechanism of these protective components from SCs is not fully understood yet, the release of these SC endogenous proteins including enzymes has 
already been mentioned in the last decade, as described in Section 3.1. The contribution of these SC endogenous enzymes to dairy transformation processing and final characteristics of products has been considered previously by several authors, and this issue will be discussed in Section 4.1.

\subsection{Identification of somatic cell types}

Several methods have been developed to differentiate SCs in milk, and among them, cytology methods are mainly used to visually identify the main cell types by optical microscopy (Baumert et al. 2009; Lindmark-Mansson et al. 2006; Sarikaya et al. 2004). Enzyme-linked immunosorbent assay (ELISA) was also applied for detecting and quantifying SCs, for example, by using the specific antibodies of PMNs. O'Sullivan et al. (1992) suggested to use a direct capture ELISA to diagnose bovine mastitis. In order to separate each type of SCs, immunomagnetic separation has been used for labeling the cell subpopulation. This method was successfully applied to isolate epithelial cells from bovine milk (Boutinaud et al. 2008), macrophages, and PMNs from sheep milk (Albenzio et al. 2009).

Recent advances of SC studies by flow cytometry in medicine diagnostic field give opportunities to study SCs in dairy field at the subpopulation level (Albenzio and Caroprese 2011; Leitner et al. 2000a; Reuter et al. 2014). The combination of immunofluorescence and flow cytometry allows the differentiation of cell types using specific antibodies (Kelly et al. 2000; Park et al. 1991; Riollet et al. 2001). Flow cytometry-cell sorting technologies distinguish and separate differential cells with more precise detection (Dosogne et al. 2003; Piepers et al. 2009). Compared with classical microscopy observation, flow cytometry allows counting SCs and identifying SC types with fewer samples and less time, thus allowing characterizing SCs and determining the roles of SCs in the milk.

\subsection{Various somatic cell count and composition}

The SC composition (SC types and their percentages in total SCC) in milk varies depending on many factors: animal species, breed, stage of lactation, genetics, parity, day-to-day variation, diurnal variation, milking interval, time of sampling, sampling procedures, stress and trauma, management factors, and seasonal and storage procedures (IDF 466/2013). The macrophage and PMN percentages showed an opposite trend during different stages of lactation in ewes, the highest macrophage level observed in early lactation and the highest PMN level in late lactation (Albenzio et al. 2009). In healthy bovine and ovine milk, macrophages are generally the predominant cells, while in both healthy and unhealthy goat milks, PMNs are predominant (Dulin et al. 1983; Ostensson 1993). Nevertheless, there are several contradictory examples concerning the predominant cell type in the case of healthy bovine milk, macrophages, lymphocytes, or epithelial cells becoming the main cell type according to the authors (Table 1).

Both SC count and composition are related to milk quality, but their relationship is not necessarily associated, except in the case of high SCC corresponding to a high amount of PMNs in bovine milk. SCC gives only the total amount of cells present in milk, but not the distribution of each cell type, making it difficult to have a relevant view of cell composition. Hence, milk with various SCCs and various SC compositions 
has a particular fingerprint that can lead to different final characteristics of dairy products, and this will be discussed in Section 4.

\section{Endogenous enzymes from somatic cells}

Besides protective functions in milk, SCs also provide numerous enzymes mentioned as SC endogenous enzymes in this review. These SCs as well as their endogenous enzymes have different profiles in terms of type, specificity, and activity and can be released into milk and further influence dairy processes and the quality of products. It is worthy to note that these SC endogenous enzymes are only part of all enzymes in milk, usually called milk indigenous enzymes. Actually, these indigenous enzymes in milk are well studied (Kelly et al. 2006; Kelly and Fox 2006; Kelly and McSweeney 2003), in particular the plasmin system (Ismail and Nielsen 2010). In this review, we will focus on SC endogenous enzymes.

\subsection{Somatic cells: an important source of enzymes}

SCs are an important source of endogenous proteins, including enzymes. A large range of enzymes are released into milk after the lysis of SCs, and among them, lipases (e.g., lipoprotein lipase), oxidases (e.g., catalase and lactoperoxidase), glycosidases (e.g., lysozyme), and proteases (e.g., cathepsins, elastase, and collagenase). The recent advances in proteomic methods have given rise to the identification of numerous proteins from SC (Jethwaney et al. 2007; Lippolis and Reinhardt 2005). Comparison of proteomes from macrophages (Dupont et al. 2004) and milk fat globule membranes (Smolenski et al. 2006) shows that they have many proteins including enzymes in common: annexin, vimentin, and apolipoprotein, $\alpha$-enolase, heat shock protein, actin, capping protein (involved in cell motility), NADP1-dependent isocitrate dehydrogenase. Even if such similarities could be partly due to the extraction of proteins in the fat layer in which SCs can be trapped and lysed at high-speed centrifugation (Smolenski et al. 2006), we cannot exclude the release of these proteins in milk as a natural phenomenon or during technological processes that can lead to underestimating their role in the final quality of dairy products.

It is only recently that a proteomic approach of the mammary epithelial cells coupled with RT-PCR and Western blotting has been developed, to give an insight into the proteins originated from this cell type in the milk and their expression (Janjanam et al. 2013). Four hundred ninety-seven proteins were identified, and some of them were identical to those originating from milk fat globule membrane (37\%) and in lactating mammary tissue (54\%), while 247 represented new mammary epithelial cell proteins.

The presence of SC endogenous enzymes in milk also suggests the occurrence of leakage or secretion of these endogenous enzymes from SCs (Kelly and Fox 2006). This is the case for cathepsin D, an endogenous enzyme from SCs detected in skim milk or whey (Larsen et al. 2006). It can degrade intracellular proteins and participate in extracellular proteolysis when it is secreted out of SCs (Briozzo et al. 1988). Dupont et al. (2004) confirmed the secretion of some SC endogenous enzymes from macrophages. The main endogenous enzymes from SC in milk are generally from macrophages and PMNs. The location of these endogenous enzymes prior to release into milk is given in Table 2. 


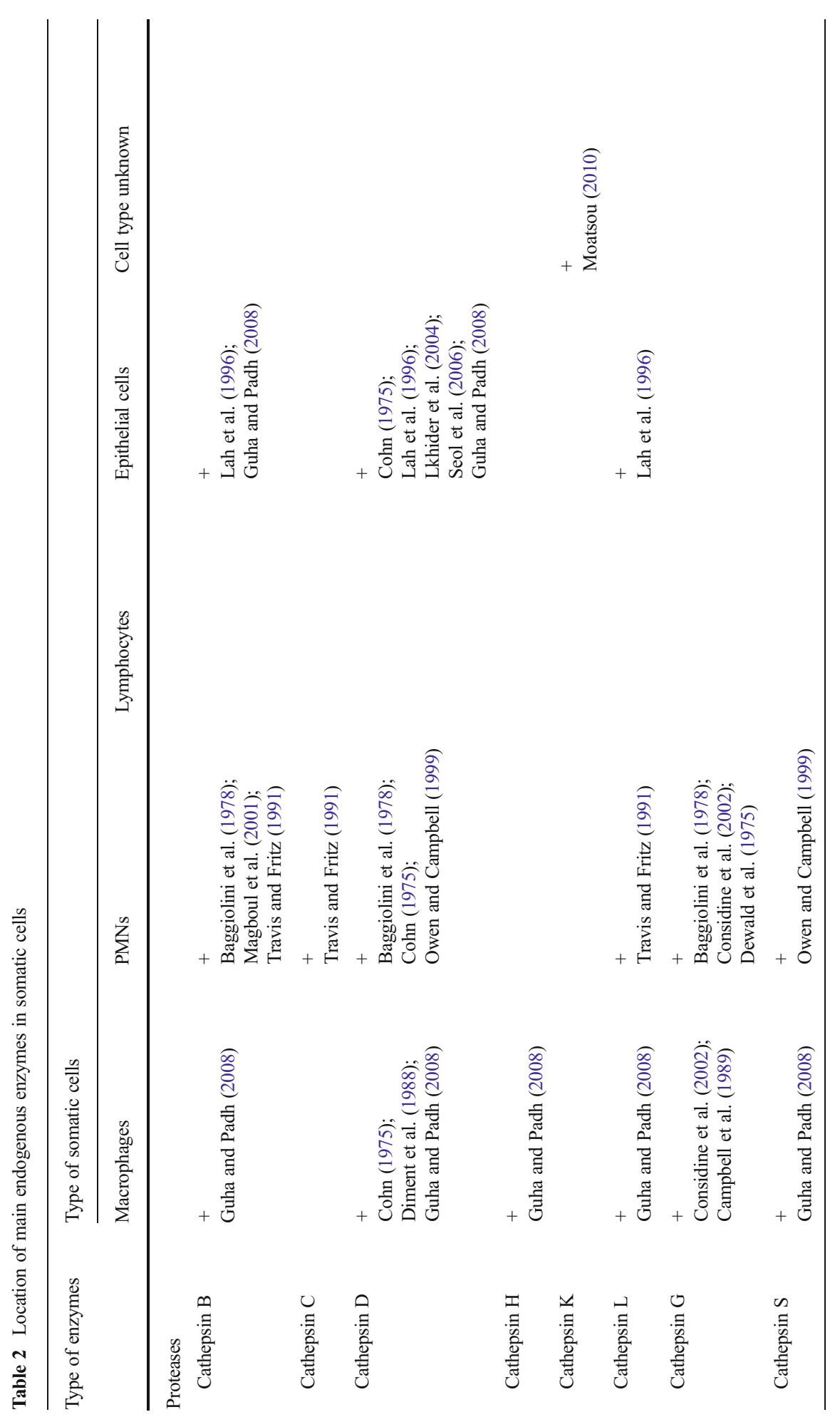




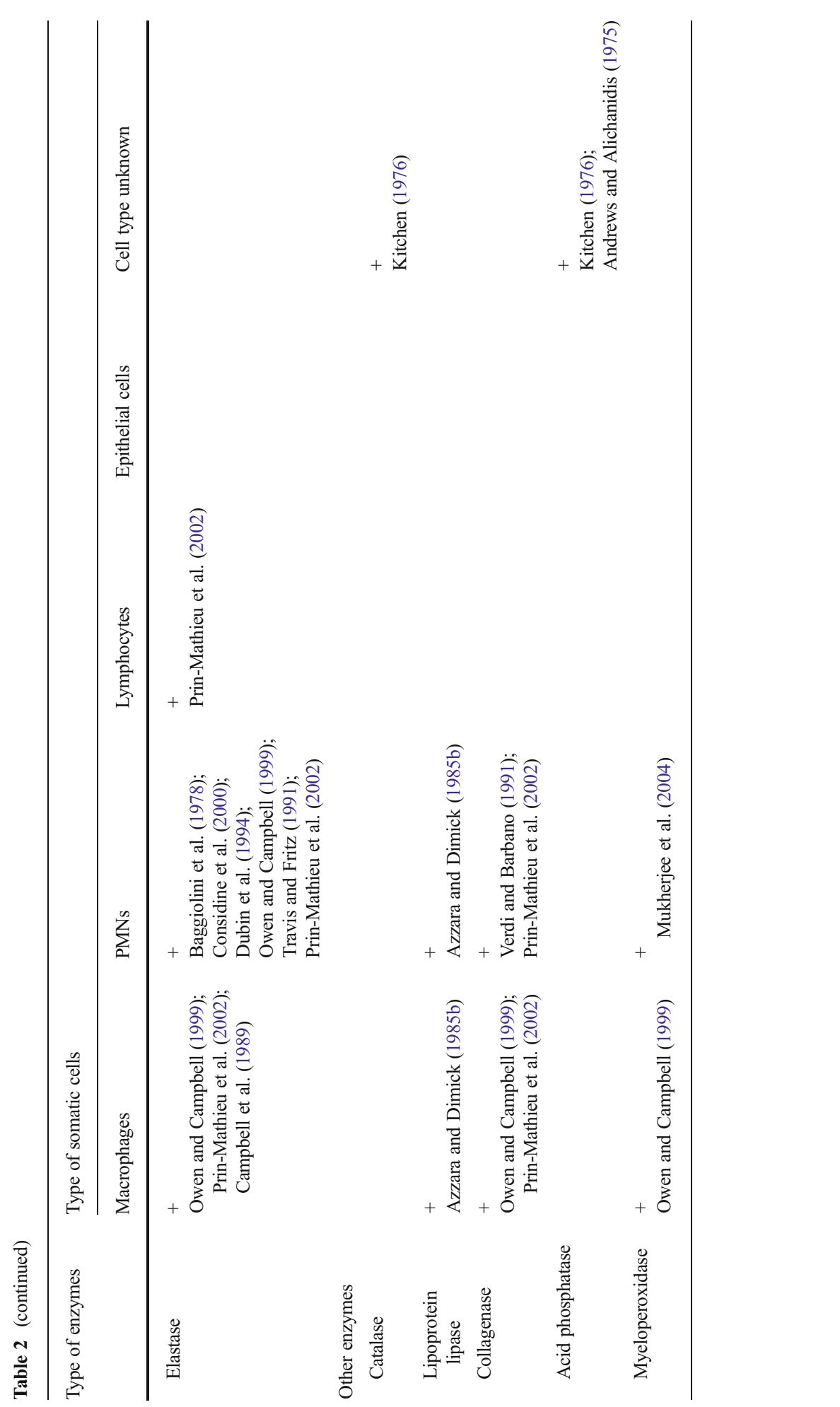

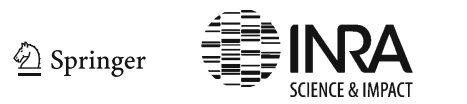


Most of the endogenous enzymes from SCs are not identified in milk and, among them, proteolytic enzymes. In fact, due to a high-dynamic range in a concentration of proteins in milk that can vary by at least a factor of $10^{6}$ between caseins and other minor proteins (Gagnaire et al. 2009), most of the proteolytic enzymes from SC are in a concentration that is so low that they are only detected through their activity or immunological studies (Magboul et al. 2001). This part will be discussed below. Additionally, the kinetics of SC death and the dynamics of enzyme release are difficult to measure and still unknown in milk and a fortiori in dairy products.

\subsection{Proteolysis of caseins by endogenous enzymes from somatic cells}

Among the numerous endogenous enzymes from SCs, proteases are by far the most studied. They are active on caseins in milk as well as during transformation processes. They can therefore modify casein degradation of dairy products, give different textural and organoleptic characteristics to final dairy products, and even reduce the cheese yield (Grappin et al. 1999).

To determine the activity of SC proteases in milk, two strategies are often used: (i) addition of commercially available proteases to milk proteins and study of protein degradation (mainly caseins) and (ii) testing activities of commercial proteases either on caseins or synthetic substrates with or without the addition of inhibitors. Proteolytic activities of commercially available cathepsins B, D, and G and elastase as well as their enzymatic specificity (sites of cleavages) have been determined on $\alpha_{\mathrm{s} 1}$ - and $\beta$-caseins (Considine et al. 1999, 2000, 2002, 2004; Hurley et al. 2000; Kelly and McSweeney 2003; McSweeney et al. 1995). Some other authors (Magboul et al. 2001; Somers et al. 2003) used enzymes extracted from acid whey, or they directly studied the proteolytic activities of endogenous enzymes in milk with different SCCs. Endogenous proteases from SCs, such as cathepsins B and G and elastase, were confirmed as responsible for the hydrolysis of $\alpha_{\mathrm{s} 1}$ - and $\beta$-caseins. Consequences on casein hydrolysis were recently shown after exposure to lipopolysaccharide from the cell walls of gram-negative E. coli, inducing an increase in SCC without bacterial damage (Hinz et al. 2012; Olumee-Shabon et al. 2013). Thus, casein proteolysis was higher in bovine (Hinz et al. 2012) than in caprine milk (Olumee-Shabon et al. 2013), and the main casein hydrolyzed was both $\alpha_{\mathrm{s} 1}$ - and $\beta$-caseins in bovine and caprine milk. At least, plasmin, elastase, and cathepsins B and D were shown to participate in the casein degradation.

Cathepsin D can hydrolyze all caseins ( $\alpha_{\mathrm{s} 1^{-}}, \alpha_{\mathrm{s} 2^{-}}, \beta$ - and $\mathrm{k}$-caseins) and was more active on $\alpha_{\mathrm{s} 1}$-caseins than on the other caseins with a broad range of cleavage sites (Hurley et al. 2000; McSweeney et al. 1995). It showed cleavage sites similar to chymosin, the main active protease from rennet used in cheese-making process, responsible for the coagulation of milk and causing the milk to separate into curds and whey. Furthermore, cathepsin B has common cleavage sites with cathepsin D and chymosin, notably on $\mathrm{Phe}_{23}-\mathrm{Phe}_{24}$ bond of $\alpha_{\mathrm{s} 1}$-casein (Magboul et al. 2001).

\subsection{Various profiles of endogenous enzymes from somatic cells}

SC endogenous enzymes show different activities according to their initial location in the cell types (Table 2). The activity of cathepsin D in induced alveolar macrophages was detected to be 60-fold higher than that in PMNs (Cohn 1975), while it was not 
detectable in lymphocytes (Barabasi and Nassberger 1994). Due to different SC counts and compositions during lactation, the activities of cathepsin D, cysteine proteases (e.g., cathepsin B), and another unidentified milk proteinase measured in milk from the same group of cows fluctuate during lactation (Larsen et al. 2006). Additionally, the presence of some SC endogenous enzymes in milk can change the activity of other enzymes in milk. For example, plasminogen activators, of which one is associated with SC, can modify plasmin activity (Albenzio et al. 2004; Politis and Ng-Kwai-Hang 1988). Such an increase in plasmin activity was observed for SCC below $1 \times 10^{5}$ cells. $\mathrm{mL}^{-1}$ and represented about $42 \%$ of that observed with high SCC $>6 \times 10^{5}$ cells. $\mathrm{mL}^{-1}$ (Le Roux et al. 2003). However, as SC types present in milk were generally not determined, enzymatic activities in milk were considered as heterogeneous (Santos et al. 2003).

The profiles of endogenous enzymes in terms of type, quantity, and activity can be influenced by different SC counts and compositions in milk. Nevertheless, their relationship during milk treatments, cheese processing, and cheese quality is still unknown. The activity of SC proteases was enhanced, while SCC increased (Kelly et al. 2006; O'Farrell et al. 2002). Elastase, one protease mainly present in PMNs, has significantly higher activity when PMNs are massively recruited into milk during infection (Le Roux et al. 2003). The elastase activity was also illustrated to have a positive correlation with SCC in caprine milk (Santillo et al. 2009). Cathepsin G and lipoprotein lipase activities were detected in high-SCC milk (SCC $1.2 \times 10^{5}-2 \times 10^{6}$ cells. $\mathrm{mL}^{-1}$ ), correlated with subclinical or clinical mastitis (Azzara and Dimick 1985b). Regarding lipolysis, the lipoprotein lipase is still active after pasteurization and participates in the production of free fatty acid in milk during storage. In addition, pasteurized milk with high SCC is more susceptible to lipolysis than that with low SCC (Santos et al. 2003).

Milk with various SC counts and compositions including different profiles of endogenous enzymes leads to different patterns of proteolysis and lipolysis and finally offers different characteristics of final dairy products. However, the milk in dairy industries, mixing the milk from hundreds or thousands of cows, can minimize the variations between milks in contrast to the milk mixed from several cows in the herd and a fortiori the milk from an individual cow and the quarter milk from the individual's mammary gland. It is still difficult to ascertain a clear relationship between enzyme activities and types of SCs present in milk and to what extent one cell type would be preferable in milk to enhance final dairy product quality.

\section{Role of somatic cells and their endogenous enzymes in dairy processes and products}

The term "effect of SCs" is mentioned in several studies (Chen et al. 2010; Fernandes et al. 2008; Ma et al. 2000; Politis and Ng-Kwai-Hang 1988; Santos et al. 2002). However, its definition is too imprecise by far. The effect of SCs in these studies includes two aspects: (i) the direct action of SCs themselves and that of their endogenous contents and (ii) the consequence of concomitant high levels of invading bacteria inducing major compositional and physicochemical changes of milk with different modified SCC levels in milk (Albenzio et al. 2011; Somers et al. 2003). As the latter 
aspect is usually associated with inflammation of the mammary gland, the effect of SC is generally ill-defined leading to confusion with other cofactors, recognized as negative for the researchers and dairy farmers.

In this part, the role of SCs and their impacts on dairy products will be considered. As these literature data concern the effect of SCs in a general way, it is difficult to focus only on the effective role of SCs excluding the influence of other factors associated in the experiments. Hence, these literature data will be discussed here in two parts: in Section 4.1, in which data clearly indicate the participation of some individual endogenous enzymes from SCs on dairy processes and products, and in Section 4.2, in which data concern the general effect of SCs. In addition, different methods of SC preparation used in these studies will be compared in order to bring out a new approach to study the effective role of SCs in the dairy field in the future.

\subsection{Participation of endogenous enzymes from somatic cells}

The milk indigenous enzymes (including SC endogenous enzymes) were indicated as active in the udder in which the temperature is optimal for most mammalian enzymes. They continued to accumulate their enzyme activities even if these activities could be weak during the refrigerated storage (dairy farm or plant) and modified the characteristics of dairy-processed products (Kelly and Fox 2006). The roles of SC enzymes have been underestimated until now because of the presence of other numerous enzymes in milk: (i) enzymes coming from the blood and present in milk, such as plasmin; (ii) added enzymes during the cheese-making process such as calf rennet (chymosin and pepsin) or fungal rennet; and (iii) enzymes produced by microflora which play an essential role in the final characteristics of cheese, such as texture and flavor. The direct action of SC endogenous enzymes, in particular cathepsin D, in dairy processes and products will be discussed below.

\subsubsection{Cathepsin D in cheese}

Among the enzymes from SCs, cathepsin D is one of the most studied endogenous enzymes in milk and different types of cheeses. It is a lysosomal acidic protease, which has been greatly discussed in the human medical domain for more than a century because of its multifunctions such as a tumor marker and a cancer indicator (Benes et al. 2008; Minarowska et al. 2008). In the dairy field, studies have increased over the past two decades.

The amount of cathepsin D was measured for the first time by Larsen et al. (1996) in bovine skim milk at $0.4 \mu \mathrm{g} . \mathrm{mL}^{-1}$ level, mainly located in whey at $0.3 \mu \mathrm{g} . \mathrm{mL}^{-1}$ level. It is four- to sevenfold higher in small ruminant milk about $1.8-2.6 \mu \mathrm{g} \cdot \mathrm{mL}^{-1}$ (Albenzio et al. 2009; Santillo et al. 2009). Five molecular forms were identified in bovine milk (Larsen and Petersen 1995): the two inactive forms preprocathepsin D (ppCD) and procathepsin D (pCD) and the three active forms pseudocathepsin D (pdCD), singlechained cathepsin D and two-chained cathepsin D (heavy- and light-chained cathepsin D). In bovine milk, the main form is the inactive form $\mathrm{pCD}$ which becomes the active form pdCD under acidic medium conditions (Larsen et al. 1993). The amino acid sequence and three-dimensional structure are close to that of two other aspartic proteinases, chymosin and pepsin (Baldwin et al. 1993). The activator-inhibitor system of cathepsin D is only partly known (Minarowska et al. 2009). Moreover, cathepsin D 
is able to survive most heat treatments applied during cheese manufacture (Table 3 ). It is also baroresistant (Moatsou et al. 2008) and stable over a range of acid $\mathrm{pH}$ values, from $\mathrm{pH} 3.5$ to 7 (Lee et al. 1998).

The presence and the activity of cathepsin D have also been illustrated in experimental rennet-free cheese and hard-cooked cheese, in which the rennet is absent or inactivated, respectively (Cooney et al. 2000; Garnot and Mollé 1987; Igoshi and Arima 1993). The presence of intact $\mathrm{pCD}$ and an active form derived from $\mathrm{pCD}$ was indicated to participate in the proteolysis process of experimental rennet-free UF-Feta cheese (Larsen et al. 2000). Furthermore, the coagulation activity of cathepsin D was confirmed in ewe milk (Albenzio et al. 2009) and in Cheddar cheese (Hurley et al. 1999). According to Santillo et al. (2009), cathepsin D concentration in caprine milk was negatively correlated with casein and protein level, possibly as a consequence of the hydrolysis capability of this enzyme. In caprine milk, cathepsin D activity was not correlated with SCC in contrast to bovine milk in which this link has been shown (Cooney et al. 2000; Kelly 1999; O’Brien et al. 2001).

\subsubsection{Other endogenous enzymes from somatic cells in dairy processes and products}

Due to the various endogenous enzymes from SCs (shown in Section 4.2) and the various physicochemical conditions encountered during cheese making and ripening, the influence of numerous SC enzymes on the final quality of dairy products could have been underestimated. Cathepsin B has similar cleavage sites to cathepsin D and chymosin; moreover, more than $20 \%$ activity of cysteine protease activity remains after heat treatment at $55{ }^{\circ} \mathrm{C}$ for $30 \mathrm{~min}$ or $72{ }^{\circ} \mathrm{C}$ for $30 \mathrm{~s}$ (Magboul et al. 2001). However, to our knowledge, there are few studies concerning the state of SCs and their endogenous enzymes during the dairy process and the contribution of SC endogenous enzymes in varied ranges of dairy products. It will be interesting to elucidate on their amount and forms trapped in the cheese curds, their contribution to proteolysis in cheese varieties, and the mechanism of their release from SCs under different milk treatment conditions such as physical, chemical, and heat treatments.

The role of other SC endogenous enzymes, such as lipoprotein lipase, is not fully understood in dairy products. Lipoprotein lipases are generally considered to be causative of flavor defaults such as "rancid" in some dairy products; they could be

Table 3 Variation of cathepsin D activity with different heat treatments

\begin{tabular}{lclll}
\hline Heat treatment & & $\begin{array}{l}\text { Residual activity }(\%) \text { at } \\
\text { optimum } \mathrm{pH}\end{array}$ & Dairy matrices & References \\
\hline Temperature $\left({ }^{\circ} \mathrm{C}\right)$ & Duration & & & \\
\hline 72 & $15 \mathrm{~s}$ & & Skim bovine milk & Hayes et al. 2001 \\
72 & $60 \mathrm{~s}$ & $\sim 50$ & Milk serum/caseins & Larsen et al. 2000 \\
& & Milk serum & Larsen et al. 2000 \\
65 & $30 \mathrm{~min}$ & $<10$ & Milk caseins & \\
55 & $30 \mathrm{~min}$ & 45 & Buffer solution & Larsen et al. 2000 \\
& & Skim bovine milk & Hayes et al. 2001
\end{tabular}


ignored or underestimated compared to high lipolytic activities brought by Penicillium roqueforti in blue cheeses; they could even be responsible for the desirable flavors (e.g., "picante" flavor) in dairy products for certain consumers. The real contribution of lipase is more difficult to ascertain, due to the numerous origins of lipolytic enzymes that can be also present in cheese. Nevertheless, the desirable but weak lipolysis observed in Swiss-type cheeses is mainly due to the ripening flora Penicillium freudenreichii rather than to the lipoprotein lipase being rapidly inactivated during heat treatment of cheese making (Dherbécourt et al. 2010).

\subsection{Role of somatic cells}

Before discussing the effective role of SCs in the dairy field, it is of great importance to understand the methodologies used in literature, such as types of milk, methods of preparing SCs, and to what extent such approaches can influence final results and interpretation. This part will primarily discuss different approaches used to study the effect of SC as shown in Table 4.

\subsubsection{Different approaches to prepare somatic cells and to study their effect}

(i) Use of individual milk or quarter milk

This method is based on separately collecting individual milk or quarter milk. There are few studies carried out with this method due to great differences between individual milk samples in terms of milk composition and SC content. In the case of high SCC $\left(>10^{6}\right.$ cells.mL $\left.{ }^{-1}\right)$, the effect of SCs takes into account other cofactors such as differences between milk samples and the contaminants in milk leading to mastitis. The effect of SCC and the stage of lactation on the quality of various products were studied, such as raw milk, ultrahigh-temperature milk, Cheddar cheese, and full cream milk powder (Auldist et al. 1996a, b, c). One study involving injection of Streptococcus agalactiae in a quarter of milk compared the shelf-life of milk containing low and high SCC on the same cows before and after infection (Ma et al. 2000). The low-SCC milk kept a high organoleptic quality during cold storage, even 21 days of shelf-life after pasteurization, in contrast to the high-SCC milk that became rancid, bitter, and astringent. This was correlated with higher lipolysis and proteolysis in high-SCC milk.

(ii) Mix of milk from healthy and mastitic cows

Mixing healthy cow milk containing low SCC with mastitic cow milk containing high SCC in different proportions allows the different SCC levels to be obtained easily and accurately (Cooney et al. 2000; O'Farrell et al. 2002; Rogers and Mitchell 1994). It is difficult to extract information regarding the effective role of the SC from these experiments, since the resulting milk combined the composition of healthy and mastitic milk as well as the various SC counts and compositions. Rogers and Mitchell (1994) found that the organoleptic grade of yoghurt made with low-SCC milk $\left(<2.5 \times 10^{5}\right.$ cells. $\left.\mathrm{mL}^{-1}\right)$ was superior to that manufactured from high-SCC milk $\left(>5 \times 10^{5}\right.$ cells $\left./ \mathrm{mL}-1\right)$. The quality of Swisstype cheese, e.g., cheese moisture, salt, $\mathrm{pH}$, and eye production during ripening, was unaffected by SCC, and the patterns of proteolysis in cheese were altered, but this may be due to a number of factors rather than SCC (Cooney et al. 2000).

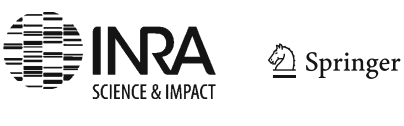




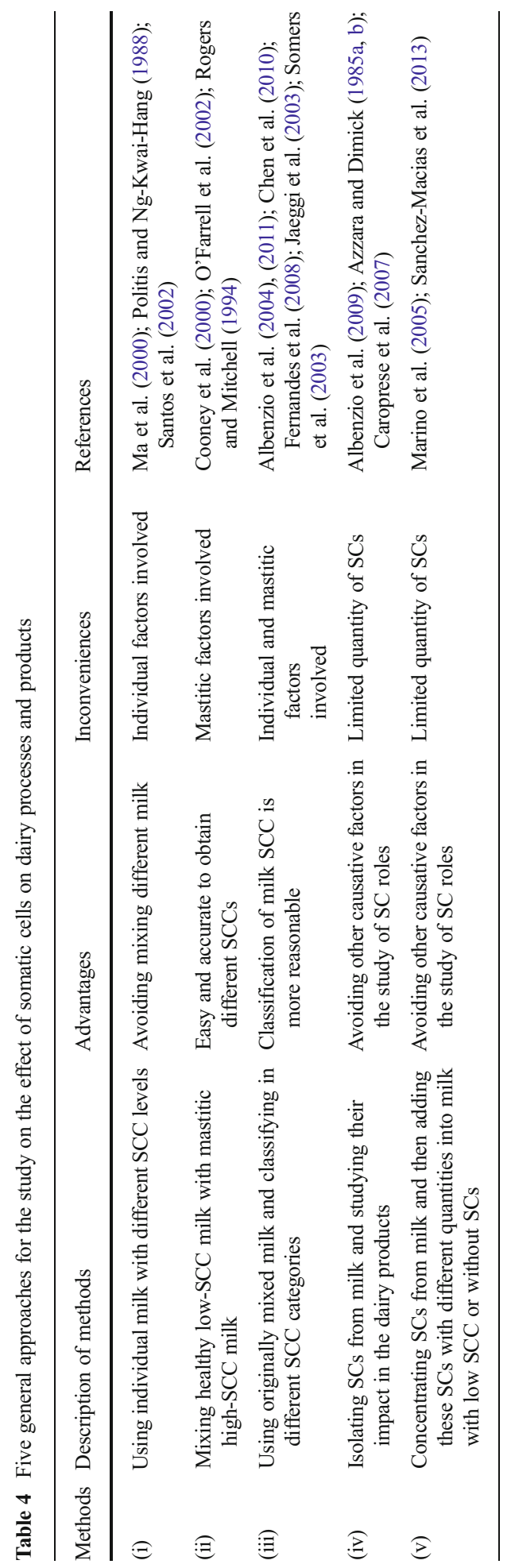


(iii) Use of originally mixed milk

Collecting the originally mixed milk with different SCCs and classifying it into different SCC categories has often been used in recent years. Nevertheless, it involves both individual differences of milk and other causative factors in the results of the effect of SCs. To have information on the effective role of SCs, interpretation has to be focused on the results of healthy low-SCC experiments. It was shown that Prato cheese made with low-SCC cow milk $\left(<2 \times 10^{5}\right.$ cells. $\left.\mathrm{mL}^{-1}\right)$ had a lower number of yeasts and molds, which usually cause deterioration of products (Vianna et al. 2008). Albenzio et al. (2004) have shown that the cheese curds made from low-SCC ewe milk $\left(<5 \times 10^{5}\right.$ cells. $\left.\mathrm{mL}^{-1}\right)$ contribute to improve the sensory properties of Canestrato Pugliese cheese during ripening. Additionally, SC count and composition were both parameters associated with the enzyme evolution of milk that contributes to a proteolytic pattern of ewe milk and to cheese sensory quality. For example, macrophages, by producing urokinase-plasminogen activators, were able to regulate the plasminogen-plasmin system that strongly influences cheese ripening.

(iv) Isolating somatic cells from milk

Isolating SCs from milk and then adding them to healthy milk seem perfect to study the effective role of SCs on milk and dairy products as well as selecting one or more cell types and their endogenous enzymes according to the origin of the cells used. The simple method of centrifugation and the advanced methods such as cell sorting flow cytometry and magnetic separation were applied for the cell isolation. Nevertheless, a relatively elevated quantity of milk is required in the case of low-SCC milk from healthy animals to obtain an adequate quantity of SCs. This may be the reason why the study on the effect of SCs until now has been only carried out on milk proteins, rather than on dairy products.

By centrifugation, SCs were isolated as a cell pellet from milk and were prepared in a cell suspension for cell analysis. Nevertheless, only one fourth or less of all SCs in milk was obtained in the precipitated pellet (Prescott and Breed 1910), and whether the small fraction in cell pellet has a fairly constant proportion of whole cells is still a question. By using Ficoll discontinuous density gradient, SCs were isolated from the milk of healthy or mastitic cows. Macrophages were then separately maintained in cell cultures to secrete lipolytic enzymes into the medium. These secreted lipolytic enzymes bind to the fat globule membranes in milk and expose the fat to degradation over storage. The other cell types, PMNs and lymphocytes, did not show lipoprotein lipase activity (Azzara and Dimick 1985a, b). Recently, using a magnetic positive separation method, Caroprese et al. (2007) have isolated macrophages from sheep milk and shown their proteolytic ability on $\alpha_{\mathrm{s}}$-caseins $(\sim 20 \%), \beta$-casein $(\sim 10 \%)$, and minor degradation on $\gamma$-casein $(\sim 1 \%)$. Using the same method, Albenzio et al. (2009) isolated not only macrophages but also PMNs from sheep milk. It has been shown that PMNs release lysosomal enzymes that induce a more intense hydrolysis on casein in late rather than in early lactation and positive correlation between these endogenous enzymes (e.g., cathepsin D) and clotting time.

(v) Concentrating somatic cells in milk

Concentrating SCs from milk and then adding different quantities to milk with low SCC or without SCs seem like a more feasible method to study the effective role of SC on milk and on cheese as well. This is a way to collect SCs with a peculiar 
composition including mainly macrophages, lymphocytes, or PMNs rather than to collect only PMNs from mastitic milk and also to vary the SCC with the same cell type. To our knowledge, Marino et al. (2005) were the first to study the contribution of SC and their proteolytic enzymes in Cheddar-type cheese by adding different quantities of concentrated SCs in a milk containing low SCs $\left(<150,000\right.$ cells.mL $\left.{ }^{-1}\right)$ for cheese making. The milk used to concentrate SCs was collected from milk with $>10^{6}$ cells. $\mathrm{mL}^{-1}$ to obtain a necessary quantity of SCs. Their results suggested that SCs have a direct influence on cheese moisture content and contribute to proteolysis in milk and Cheddar-type cheese. As mentioned in Section 3.3, the milk from mastitic and healthy cows with different SC counts and compositions has different profiles of $\mathrm{SC}$ endogenous enzymes. The cow milk used in this experiment was mastitic so it was mainly composed of PMNs; as a result, the effect of SCs is supposed to be interpreted as the "effect of PMNs." Recently, the effect of SCs concentrated from healthy goat milk was studied on low-fat cheese in order to improve cheese sensorial quality (Sanchez-Macias et al. 2013). Only miniature fresh goat milk cheeses were made in these experiments due to the limited quantity of collected SCs. Even if the ripening period lasted only 7 days, a general reduction in casein fractions was observed in the cheese with added SCs: $\beta$-casein (43 vs $26 \%$ ), para-K-casein (37 vs $23 \%$ ), $\alpha_{\mathrm{s} 2}$-casein (30 vs $20 \%$ ), and $\alpha_{\mathrm{s} 1}$-casein ( 25 vs $14 \%$ ). Different patterns of casein degradation were found, while SCC was increased in raw or pasteurized goat milk cheeses. Moreover, cheeses with added SC were found to have softer texture and incremental color without any modification of chemical composition (SanchezMacias et al. 2013). Even if the SC composition was not determined in this study, the main SCs in healthy goat milk are PMNs (Dulin et al. 1983; Ostensson 1993), which are the same predominant cell type in mastitic cow milk (Azzara and Dimick 1985b). Until now, no study on the effective role of SCs on milk and on cheese has been conducted with healthy cow milk.

\subsubsection{A new approach to study the effective role of somatic cells}

It is worth noting that different milks and different methods of preparing SCs from milk can both induce different consequences on SCs themselves and then different roles of SCs on dairy processes and products. Adding isolated or concentrated SC with different ratios to cheese milk with low SCC or ideally without SCs will be a good strategy to study the effective role of SCs on dairy products. With the development of membrane filtration techniques in the dairy field (Saboya and Maubois 2000), the selective separation of SCs from raw milk becomes possible and feasible in practical experiments. Comparing other SC preparation technologies to study the role of SCs, the main advantages of membrane filtration techniques are listed below: (i) a great quantity of SCs can be efficiently concentrated at an industrial scale. Thus, collecting sufficient SCs from healthy milk originally poor in SCs is no longer a limiting step, and making diverse dairy products and analyzing the lipolysis and proteolysis in a long term become achievable; (ii) by membrane filtration, the milk deprived in SCs can be obtained by keeping the maximum native characteristics of milk. This SC-free milk can be used as the control in which SCs can be added in different quantities for cheese making. By using the same standardized milk in cheese making, the individual factors between different milk samples in other studies can 
be excluded; (iii) SCs can be added in different quantities to SC-free milk. Even with a high-added SCC level, the mastitic factors in other studies can be also excluded in this new approach; (iv) the studies on the effect of different SC types can be considered by concentrating SCs from different milk samples, for example, healthy bovine milk enriched in macrophages and mastitic bovine milk enriched in PMNs. However, several aspects of this new approach should be considered: the choice of membrane for optimized filtration, microfiltration, or ultrafiltration; the coseparation of other components in milk such as fat, proteins, and bacteria; and the influence of membrane filtration on the SCs, and to what extent, the final dairy products are affected.

\section{Conclusion and perspectives}

Although different approaches to study the effect of SCs have been conducted, few protocols have been undertaken to highlight the effective role of SCs on dairy products without the other concomitant factors in high-SCC milk. In this review, a new approach to study the effective role of SCs on dairy processes and products is suggested by comparing relevant methods of preparing SC. Isolating or concentrating SCs from milk and adding these SCs at different ratios in SC-free milk seems to be a good strategy. The milk status (mastitis or not mastitis and subclinical, chronic, or acute mastitis), SCC, and SC profiles should be precisely defined. This would allow the control of SC count and composition and, therefore, their endogenous enzyme profiles in milk. Such a fingerprint would help to characterize more precisely the SC impact on technological properties and final quality of dairy products besides the initial microbiological and nutritional characteristics of milk.

By analyzing the literature data, we have pointed out in this review that SCs can have a desirable role, in terms of acceleration of proteolysis in the cheese-ripening process and improvement of cheese sensory quality. Many studies remain to be done to fully understand the effective role of SCs, each cell type, and their extent in the dairy field. In particular, the relationship between SCs and their endogenous enzymes as well as the mechanism by which endogenous enzymes are released from SCs under different conditions and during dairy processes need to be elucidated.

Acknowledgments We are grateful to Mary Bret for the English correction of this paper.

Open Access This article is distributed under the terms of the Creative Commons Attribution License which permits any use, distribution, and reproduction in any medium, provided the original author(s) and the source are credited.

\section{References}

Albenzio M, Caroprese M (2011) Differential leucocyte count for ewe milk with low and high somatic cell count. J Dairy Res 78:43-48

Albenzio M, Caroprese M, Santillo A, Marino R, Taibi L, Sevi A (2004) Effects of somatic cell count and stage of lactation on the plasmin activity and cheese-making properties of ewe milk. J Dairy Sci 87:533542

Albenzio M, Santillo A, Caroprese M, D’Angelo F, Marino R, Sevi A (2009) Role of endogenous enzymes in proteolysis of sheep milk. J Dairy Sci 92:79-86 
Albenzio M, Santillo A, Caroprese M, Schena L, Russo DE, Sevi A (2011) Composition, indigenous proteolytic enzymes and coagulating behaviour of ewe milk as affected by somatic cell count. J Dairy Res 78:442-447

Andrews AT, Alichanidis E (1975) The acid phosphatases of bovine leucocytes, plasma and the milk of healthy and mastitic cows. J Dairy Res 42:391-400

Auldist MJ, Coats ST, Sutherland BJ, Clarke PT, McDowell GH, Rogers GL (1996a) Effect of somatic cell count and stage of lactation on the quality of full cream milk powder. Aust J Dairy Technol 51:94-98

Auldist MJ, Coats SJ, Sutherland BJ, Hardham JF, McDowell GH, Rogers GL (1996b) Effect of somatic cell count and stage of lactation on the quality and storage life of ultra high temperature milk. J Dairy Res 63: 377-386

Auldist MJ, Coats S, Sutherland BJ, Mayes JJ, McDowell GH, Rogers GL (1996c) Effects of somatic cell count and stage of lactation on raw milk composition and the yield and quality of cheddar cheese. J Dairy Res 63:269-280

Azzara CD, Dimick PS (1985a) Lipolytic enzyme activity of macrophages in bovine mammary gland secretions. J Dairy Sci 68:1804-1812

Azzara CD, Dimick PS (1985b) Lipoprotein lipase activity of milk from cows with prolonged subclinical mastitis. J Dairy Sci 68:3171-3175

Baggiolini M, Bretz U, Dewald B, Feigenson ME (1978) The polymorphonuclear leukocyte. Inflamm Res 8: $3-10$

Baldwin ET, Bhat TN, Gulnik S, Hosur MV, Sowder RC, Cachau RE, Collins J, Silva AM, Erickson JW (1993) Crystal structures of native and inhibited forms of human cathepsin-D: implications for lysosomal targeting and drug design. Biochem US 90:6796-6800

Barabasi K, Nassberger L (1994) Distribution of cathepsin-D in human polymorphonuclear and mononuclear blood cells. APMIS 102:89-93

Baumert A, Bruckmaier RM, Wellnitz O (2009) Cell population, viability, and some key immunomodulatory molecules in different milk somatic cell samples in dairy cows. J Dairy Res 76:356-364

Ben Chedly H, Lacasse P, Marnet PG, Komara M, Marion S, Boutinaud M (2011) Use of milk epithelial cells to study regulation of cell activity and apoptosis during once-daily milking in goats. Animal 5:572-579

Benes P, Vetvicka V, Fusek M (2008) Cathepsin D_many functions of one aspartic protease. Crit Rev Oncol Hematol 68:12-28

Benic M, Habrun B, Kompes G, Mihaljevic Z, Cvetnic Z, Cergolj M, Macesic N (2012) Cell content in milk from cows with $S$. aureus intramammary infection. Vet Arh 82:411-422

Boulaaba A, Grabowski N, Klein G (2011) Differential cell count of caprine milk by flow cytometry and microscopy. Small Rumin Res 97:117-123

Boutinaud M, Jammes H (2002) Potential uses of milk epithelial cells: a review. Reprod Nutr Dev 42:133-147

Boutinaud M, Ben Chedly MH, Delamaire E, Guinard-Flament J (2008) Milking and feed restriction regulate transcripts of mammary epithelial cells purified from milk. J Dairy Sci 91:988-998

Briozzo P, Morisset M, Capony F, Rougeot C, Rochefort H (1988) In vitro degradation of extracellular matrix with Mr 52,000 cathepsin D secreted by breast cancer cells. Cancer Res 48:3688-3692

Burvenich C, Van MV, Mehrzad J, Diez-Fraile A, Duchateau L (2003) Severity of E. coli mastitis is mainly determined by cow factors. Vet Res 34:521-564

Campbell EJ, Silverman EK, Campbell MA (1989) Elastase and cathepsin G of human monocytes. Quantification of cellular content, release in response to stimuli, and heterogeneity in elastase-mediated proteolytic activity. J Immunol 143:2961-2968

Caroprese M, Marzano A, Schena L, Marino R, Santillo A, Albenzio M (2007) Contribution of macrophages to proteolysis and plasmin activity in ewe bulk milk. J Dairy Sci 90:2767-2772

Chen SX, Wang JZ, Van Kessel JS, Ren FZ, Zeng SS (2010) Effect of somatic cell count in goat milk on yield, sensory quality, and fatty acid profile of semisoft cheese. J Dairy Sci 93:1345-1354

Cohn ZA (1975) The role of proteases in macrophage physiology. In: Reich, Rifkin, Shaw (eds) Proteases and biological control. Cold Spring Harbour Laboratory, New York, pp 483-491

Considine T, Healy A, Kelly AL, McSweeney PLH (1999) Proteolytic specificity of elastase on bovine $\beta$ casein. Food Chem 66:463-470

Considine T, Healy A, Kelly AL, McSweeney PLH (2000) Proteolytic specificity of elastase on bovine $\alpha_{\mathrm{s} 1^{-}}$ casein. Food Chem 69:19-26

Considine T, Geary S, Kelly AL, McSweeney PLH (2002) Proteolytic specificity of cathepsin G on bovine $\alpha_{\mathrm{s} 1^{-}}$and $\beta$-caseins. Food Chem 76:59-67

Considine T, Healy A, Kelly AL, McSweeney PLH (2004) Hydrolysis of bovine caseins by cathepsin B, a cysteine proteinase indigenous to milk. Int Dairy J 14:117-124 
Cooney S, Tiernan D, Joyce P, Kelly AL (2000) Effect of somatic cell count and polymorphonuclear leucocyte content of milk on composition and proteolysis during ripening of Swiss-type cheese. J Dairy Res 67: 301-307

Council Directive 92/46/EEC (1992) European Union: Health rules for the production and placing on the market of raw milk, heat-treated milk and milk based products regulations. CELEX-EUR Official Journal L 268:1-31

Dewald B, Rindler-Ludwig R, Bretz U, Baggiolini M (1975) Subcellular localization and heterogeneity of neutral proteases in neutrophilic polymorphonuclear leukocytes. J Exp Med 141:709-723

Dherbécourt J, Bourlieu C, Maillard MB, Aubert-Frogerais L, Richoux R, Thierry A (2010) Time course and specificity of lipolysis in Swiss cheese. J Agric Food Chem 58:11732-11739

Diment S, Leech MS, Stahl PD (1988) Cathepsin D is membrane-associated in macrophage endosomes. J Biol Chem 263:6901-6907

Dosogne H, Vangroenweghe F, Mehrzad J, Massart-Leen AM, Burvenich C (2003) Differential leukocyte count method for bovine low somatic cell count milk. J Dairy Sci 86:828-834

Dubin A, Potempa J, Travis J (1994) Structural and functional characterization of elastases from horse neutrophils. Biochem J 300:401-406

Dulin AM, Paape MJ, Schultze WD, Weinland BT (1983) Effect of parity, stage of lactation, and intramammary infection on concentration of somatic cells and cytoplasmic particles in goat milk. J Dairy Sci 66:2426-2433

Dupont A, Tokarski C, Dekeyzer O, Guihot AL, Amouyel P, Rolando C, Pinet F (2004) Two-dimensional maps and databases of the human macrophage proteome and secretome. Proteomics 4:1761-1778

Fernandes AM, Moretti TS, Bovo F, Lima CG, Oliveira CAF (2008) Effect of somatic cell counts on lipolysis, proteolysis and apparent viscosity of UHT milk during storage. Int J Dairy Technol 61:327-332

Gagnaire V, Jardin J, Jan G, Lortal S (2009) Invited review: proteomics of milk and bacteria used in fermented dairy products: from qualitative to quantitative advances. J Dairy Sci 92:811-825

Garnot P, Mollé D (1987) Heat-stability of milk-clotting enzymes in conditions encountered in Swiss cheese making. J Food Sci 52:75-77

Gonzalez-Rodriguez MC, Gonzalo C, San Primitivo F, Carmenes P (1995) Relationship between somatic cell count and intramammary infection of the half udder in dairy ewes. J Dairy Sci 78:2753-2759

Grappin R, Beuvier E, Bouton Y, Pochet S (1999) Advances in the biochemistry and microbiology of Swisstype cheeses. Lait 79:3-22

Guha S, Padh H (2008) Cathepsins: fundamental effectors of endolysosomal proteolysis. Indian J Biochem Biophys 45:75-90

Hamed H, El Feki A, Gargouri A (2008) Total and differential bulk cow milk somatic cell counts and their relation with antioxidant factors. CR Biol 331:144-151

Hayes MG, Hurley MJ, Larsen LB, Heegaard CW, Magboul AA, Oliveira JC, McSweeney PLH, Kelly AL (2001) Thermal inactivation kinetics of bovine cathepsin D. J Dairy Res 68:267-276

Hettinga K, Van Valenberg H, De Vries S, Boeren S, Van Hooijdonk T, An Arendonk J, Rvoort J (2011) The host defense proteome of human and bovine milk. PLoS One 6:e19433

Hinz K, Larsen LB, Wellnitz O, Bruckmaier RM, Kelly AL (2012) Proteolytic and proteomic changes in milk at quarter level following infusion with Escherichia coil lipopolysaccharide. J Dairy Sci 95:1655-1666

Hunt KM, Williams JE, Shafii B, Hunt MK, Mehre R, Ting R, McGuire MK, McGuire MA (2013) Mastitis is associated with increased free fatty acids, somatic cell count, and interleukin- 8 concentrations in human milk. Breastfeed Med 8:105-110

Hurley MJ, O’Driscoll BM, Kelly AL, McSweeney PLH (1999) Novel assay for the determination of residual coagulant activity in cheese. Int Dairy J 9:553-558

Hurley MJ, Larsen LB, Kelly AL, McSweeney PLH (2000) The milk acid proteinase cathepsin D: a review. Int Dairy J 10:673-681

Igoshi K, Arima S (1993) Acid and semi-alkaline proteinase in Swiss-type cheese. Milchwissenschaft 48:623-626

Ismail B, Nielsen SS (2010) Invited review: plasmin protease in milk: current knowledge and relevance to dairy industry. J Dairy Sci 93:4999-5009

ISO13366-1/IDF148-1 (2008) Milk-enumeration of somatic cells - part 1: microscopic method (reference method). International Dairy Federation Standard 1-17

ISO13366-2/IDF148-2 (2006) Milk — enumeration of somatic cells — part 2: guidance on the operation of fluoro-opto-electronic counters. International Dairy Federation Standard 1-13

Jaeggi JJ, Govindasamy-Lucey S, Berger YM, Johnson ME, McKusick BC, Thomas DL, Wendorff WL (2003) Hard ewe's milk cheese manufactured from milk of three different groups of somatic cell counts. J Dairy Sci 86:3082-3089 
Janjanam J, Jamwal M, Singh S, Kumar S, Panigrahi AK, Hariprasad G, Jena MK, Anand V, Kumar S, Kaushik JK, Dang AK, Mukesh M, Mishra BP, Srinivasan A, Reddy VS, Mohanty AK (2013) Proteome analysis of functionally differentiated bovine (Bos indicus) mammary epithelial cells isolated from milk. Proteomics 13:3189-3204

Jethwaney D, Islam MR, Leidal K, De Bernabe D, Campbell K, Nauseef W, Gibson B (2007) Proteomic analysis of plasma membrane and secretory vesicles from human neutrophils. Proteome Sci 5:12-27

Kelly AL (1999) Effect of plasmin and somatic cell enzymes on proteolysis in aseptic starter and rennet free model cheeses. Milchwissenschaft 54:249-252

Kelly AL, Fox PF (2006) Indigenous enzymes in milk: a synopsis of future research requirements. Int Dairy J 16:707-715

Kelly AL, McSweeney PLH (2003) Indigenous proteinases in milk. In: Fox, McSweeney (eds) Advanced dairy chemistry - 1 proteins. Springer, US, pp 495-521

Kelly AL, Tiernan D, O’Sullivan C, Joyce P (2000) Correlation between bovine milk somatic cell count and polymorphonuclear leukocyte level for samples of bulk milk and milk from individual cows. J Dairy Sci 83:300-304

Kelly AL, O'Flaherty F, Fox PF (2006) Indigenous proteolytic enzymes in milk: a brief overview of the present state of knowledge. Int Dairy J 16:563-572

Kitchen BJ (1976) Enzymatic methods for estimation of the somatic cell count in bovine milk. 1. Development of assay techniques and a study of their usefulness in evaluating the somatic cell content of milk. J Dairy Res 43:251-258

Lah TT, Calaf G, Kalman E, Shinde BG, Somers R, Estrada S, Salero E, Russo J, Daskal I (1996) Cathepsins D, B, and L in transformed human breast epithelial cells. Breast Cancer Res Treat 39:221-233

Larsen LB, Petersen TE (1995) Identification of five molecular forms of cathepsin D in bovine milk. Adv Exp Med Biol 362:279-283

Larsen LB, Boisen A, Petersen TE (1993) Procathepsin D cannot autoactivate to cathepsin D at acid pH. FEBS Lett 319:54-58

Larsen LB, Benfeldt C, Rasmussen LK, Petersen TE (1996) Bovine milk procathepsin D and cathepsin D: coagulation and milk protein degradation. J Dairy Res 63:119-130

Larsen LB, Wium H, Benfeldt C, Heegaard CW, Ardo Y, Qvist KB, Petersen TE (2000) Bovine milk procathepsin D: presence and activity in heated milk and in extracts of rennet-free UF-Feta cheese. Int Dairy J 10:67-73

Larsen LB, McSweeney PLH, Hayes MG, Andersen JB, Ingvartsen KL, Kelly AL (2006) Variation in activity and heterogeneity of bovine milk proteases with stage of lactation and somatic cell count. Int Dairy $\mathrm{J} 16$ : $1-8$

Le Maréchal C, Thiéry R, Vautor E, Le Loir Y (2011) Mastitis impact on technological properties of milk and quality of milk products - a review. Dairy Sci Technol 91:247-282

Le Roux Y, François L, Fatima M (2003) Polymorphonuclear proteolytic activity and milk composition change. Vet Res 34:629-645

Lee CS, Wooding FBP, Kemp P (1980) Identification, properties, and differential counts of cell-populations using electron-microscopy of dry cows secretions, colostrum and milk from normal cows. J Dairy Res 47 : 39-50

Lee AY, Gulnik SV, Erickson JW (1998) Conformational switching in an aspartic proteinase. Nat Struct Biol 5:866-871

Leitner G, Chaffer M, Krifucks O, Glickman A, Ezra E, Saran A (2000a) Milk leucocyte populations in heifers free of udder infection. J Vet Med 47:133-138

Leitner G, Shoshani E, Krifucks O, Chaffer M, Saran A (2000b) Milk leucocyte population patterns in bovine udder infection of different aetiology. J Vet Med 47:581-589

Lindmark-Mansson H, Bränning C, Aldén G, Paulsson M (2006) Relationship between somatic cell count, individual leukocyte populations and milk components in bovine udder quarter milk. Int Dairy J 16:717727

Lippolis JD, Reinhardt TA (2005) Proteomic survey of bovine neutrophils. Vet Immunol Immunopathol 103: 53-65

Lkhider M, Castino R, Bouguyon E, Isidoro C, Olivier-Bousquet M (2004) Cathepsin D released by lactating rat mammary epithelial cells is involved in prolactin cleavage under physiological conditions. J Cell Sci 117:5155-5164

Ma Y, Ryan C, Barbano DM, Galton DM, Rudan MA, Boor KJ (2000) Effects of somatic cell count on quality and shelf-life of pasteurized fluid milk. J Dairy Sci 83:264-274

Magboul AA, Larsen LB, McSweeney PLH, Kelly AL (2001) Cysteine protease activity in bovine milk. Int Dairy J 11:865-872 
Marino R, Considine T, Sevi A, McSweeney PLH, Kelly AL (2005) Contribution of proteolytic activity associated with somatic cells in milk to cheese ripening. Int Dairy J 15:1026-1033

McSweeney PLH, Fox PF, Olson NF (1995) Proteolysis of bovine caseins by cathepsin D: preliminary observations and comparison with chymosin. Int Dairy J 5:321-336

Minarowska A, Gacko M, Karwowska A, Minarowski L (2008) Human cathepsin D. Folia Histochem Cytobiol 46:23-38

Minarowska A, Karwowska A, Gacko M (2009) Quantitative determination and localization of cathepsin D and its inhibitors. Folia Histochem Cytobiol 47:153-177

Moatsou G (2010) Indigenous enzymatic activities in ovine and caprine milks. Int J Dairy Technol 63:16-31

Moatsou G, Katsaros G, Bakopanos C, Kandarakis I, Taoukis P, Politis I (2008) Effect of high-pressure treatment at various temperatures on activity of indigenous proteolytic enzymes and denaturation of whey proteins in ovine milk. Int Dairy J 18:1119-1125

Morgante M, Ranucci S, Pauselli M, Casoli C, Duranti E (1996) Total and differential cell count in milk of primiparous Comisana ewes without clinical signs of mastitis. Small Rumin Res 21:265-271

Mukherjee R, Ram GC, Dash PK, Goswami T (2004) The activity of milk leukocytes in response to a water-soluble fraction of Mycobacterium phlei in bovine subclinical mastitis. Vet Res Commun 28: 47-54

O’Brien B, Meaney WJ, McDonagh D, Kelly A (2001) Influence of somatic cell count and storage interval on composition and processing characteristics of milk from cows in late lactation. Aust J Dairy Technol 56: 213-218

O'Farrell IP, Sheehan JJ, Wilkinson MG, Harrington D, Kelly AL (2002) Influence of addition of plasmin or mastitic milk to cheesemilk on quality of smear-ripened cheese. Dairy Sci Technol 82:305-316

Olechnowicz J, Jaskowski JM (2012) Somatic cells count in cow's bulk tank milk. J Vet Med Sci 74:681-686

Olumee-Shabon Z, Swain T, Smith EA, Tall E, Boehmer JL (2013) Proteomic analysis of differentially expressed proteins in caprine milk during experimentally induced endotoxin mastitis. J Dairy Sci 96 : 2903-2912

Ostensson K (1993) Total and differential leukocyte counts, $N$-acetyl- $\beta$-D-glucosaminidase activity, and serum albumin content in foremilk and residual milk during endotoxin-induced mastitis in cows. Am J Vet Res 54:231-238

O'Sullivan CA, Joyce PJ, Sloan T, Shattock AG (1992) Capture immunoassay for the diagnosis of bovine mastitis using a monoclonal antibody to polymorphonuclear granulocytes. J Dairy Res 59:122-133

Owen CA, Campbell EJ (1999) The cell biology of leukocyte-mediated proteolysis. J Leukocyte Biol 65:137-150

Paape MJ, Wergin WP, Guidry AJ, Pearson RE (1979) Leukocytes - second line of defense against invading mastitis pathogens. J Dairy Sci 62:135-153

Paape MJ, Mehrzad J, Zhao X, Detilleux J, Burvenich C (2002) Defense of the bovine mammary gland by polymorphonuclear neutrophil leukocytes. J Mammary Gland Biol 7:109-121

Paape MJ, Bannerman DD, Zhao X, Lee JW (2003) The bovine neutrophil: Structure and function in blood and milk. Vet Res 34:597-627

Park YH, Fox LK, Hamilton MJ, Davis WC (1991) Bovine mononuclear leukocyte subpopulations in peripheral blood and mammary gland secrections during lactation. J Dairy Sci 75:998-1006

Pham CTN (2006) Neutrophil serine proteases: specific regulators of inflammation. Nat Rev Immunol 6:541550

Piepers S, De Vliegher S, Demeyere K, Lambrecht BN, De Kruif A, Meyer E, Opsomer G (2009) Technical note: flow cytometric identification of bovine milk neutrophils and simultaneous quantification of their viability. J Dairy Sci 92:626-631

Politis I, Ng-Kwai-Hang KF (1988) Effects of somatic cell counts and milk composition on the coagulating properties of milk. J Dairy Sci 71:1740-1746

Prescott SC, Breed RS (1910) The determination of the number of body cells in milk by a direct method. J Infect Dis 7:632-640

Prin-Mathieu C, Le Roux Y, Faure GC, Laurent F, Bene MC, Moussaoui F (2002) Enzymatic activities of bovine peripheral blood leukocytes and milk polymorphonuclear neutrophils during intramammary inflammation caused by lipopolysaccharide. Clin Vaccine Immunol 9:812-817

Rankl JE (2004) Differentiation of somatic cells in milk of several species with special regard to epithelial cells. Faculty of Veterinary Medicine of the Ludwig Maximilian University, Munich

Raynal-Ljutovac K, Pirisi A, De Cremoux R, Gonzalo C (2007) Somatic cells of goat and sheep milk: analytical, sanitary, productive and technological aspects. Small Rumin Res 68:126-144

Reuter K, Ehmcke J, Stukenborg JB, Simoni M, Damm OS, Redmann K, Schlatt S, Wistuba J (2014) Reassembly of somatic cells and testicular organogenesis in vitro. Tissue Cell 46:86-96 
Riollet C, Rainard P, Poutrel B (2001) Cell subpopulations and cytokine expression in cow milk in response to chronic staphylococcus aureus infection. J Dairy Sci 84:1077-1084

Rivas AL, Tadevosyan R, Gorewit RC, Anderson KL, Lyman R, Gonzalez RN (2006) Relationships between the phagocytic ability of milk macrophages and polymorphonuclear cells and somatic cell counts in uninfected cows. Can J Vet Res 70:68-74

Rogers SA, Mitchell GE (1994) The relationship between somatic cell count, composition and manufacturing properties of bulk milk. 6. Cheddar cheese and skim-milk yogurt. Aust J Dairy Technol 49:70-74

Rupp R, Boichard D, Bertrand C, Bazin S (2000) Overview of milk somatic cell counts in the French dairy cattle breeds. Prod Anim 13:257-267

Saboya LV, Maubois JL (2000) Current developments of microfiltration technology in the dairy industry. Lait 80:541-553

Sanchez-Macias D, Morales-delaNuez A, Torres A, Hernandez-Castellano LE, Jiménez-Flores R, Castro N, Arguello A (2013) Effects of addition of somatic cells to caprine milk on cheese quality. Int Dairy J 29: 61-67

Santillo A, Kelly AL, Palermo C, Sevi A, Albenzio M (2009) Role of indigenous enzymes in proteolysis of casein in caprine milk. Int Dairy J 19:655-660

Santos MV, Ma Y, Barbano DM (2002) Effect of somatic cell count on pasteurized fluid milk quality. National Mastitis Council Regional Meeting Proceedings 27-30

Santos MV, Ma Y, Barbano DM (2003) Effect of somatic cell count on proteolysis and lipolysis in pasteurized fluid milk during shelf-life storage. J Dairy Sci 86:2491-2503

Sarikaya H, Prgomet C, Pfaffl MW, Bruckmaier RM (2004) Differentiation of leukocytes in bovine milk. Milchwissenschaft 59:586-589

Schwarz D, Diesterbeck US, Konig S, Brugemann K, Schlez K, Zschock M, Wolter W, Czerny CP (2011) Flow cytometric differential cell counts in milk for the evaluation of inflammatory reactions in clinically healthy and subclinically infected bovine mammary glands. J Dairy Sci 94:5033-5044

Seol MB, Bong JJ, Baik M (2006) Involvement of cathepsin D in apoptosis of mammary epithelial cells. Asian Autral J Anim 19:1100-1105

Sharma N, Singh NK, Bhadwal MS (2011) Relationship of somatic cell count and mastitis: an overview. Asian Autral J Anim 24:429-438

Smolenski G, Haines S, Kwan FYS, Bond J, Farr V, Davis SR, Stelwagen K, Wheeler TT (2006) Characterisation of host defence proteins in milk using a proteomic approach. J Proteome Res 6:207-215

Somers JM, O’Brien B, Meaney WJ, Kelly AL (2003) Heterogeneity of proteolytic enzyme activities in milk samples of different somatic cell count. J Dairy Res 70:45-50

Sordillo LM, Streicher KL (2002) Mammary gland immunity and mastitis susceptibility. J Mammary Gland Biol 7:135-146

Sordillo LM, Shafer-Weaver K, Dessauge F (1997) Immunobiology of the mammary gland. J Dairy Sci 80: 1851-1865

Souza FN, Blagitz MG, Penna CFAM, la Libera AMMP, Heinemann MB, Cerqueira MMOP (2012) Somatic cell count in small ruminants: friend or foe? Small Rumin Res 107:65-75

Travis J, Fritz H (1991) Potential problems in designing elastase inhibitors for therapy. Am Rev Respir Dis 143:1412-1415

Verdi RJ, Barbano DM (1991) Properties of proteases from milk somatic cells and blood leukocytes. J Dairy Sci 74:2077-2081

Vianna PCB, Mazal G, Santos MV, Bolini HMA, Gigante ML (2008) Microbial and sensory changes throughout the ripening of prato cheese made from milk with different levels of somatic cells. J Dairy Sci 91:1743-1750 